\title{
Atyaephyra tuerkayi Christodoulou et al., 2012 and Palaemon turcorum (Holthuis, 1961) (Decapoda, Caridea) in the Middle Eastern Region of the Mediterranean
}

\author{
Enrique González-Ortegón ${ }^{1, *}$ (D), Deniz Innal ${ }^{2}$, Jose A. Cuesta ${ }^{1}$
}

${ }^{1}$ Instituto de Ciencias Marinas de Andalucía (ICMAN-CSIC), Avda. República Saharaui, 2, 11519 Puerto Real, Cádiz, Spain.

${ }^{2}$ Mehmet Akif Ersoy University, Department of Biology, 15030 Burdur, Turkey

\section{Article History}

Received 09 October 2020

Accepted 24 December 2020

First Online 25 December 2020

\section{Corresponding Author}

Tel.: +34956832612

E-mail: quique.gonzalez@icman.csic.es

\section{Keywords}

Atyidae

Palaemonidae

COI

$16 \mathrm{~S}$

Distribution

Pleopod

Cryptic species

\begin{abstract}
The real distribution range of a species is mostly unknown due to the lack of sampling in certain regions in the world. This may be especially problematic for freshwater species in the Mediterranean basin since its freshwater inhabitants are taxa highly sensitive to anthropogenic disturbances. The cytochrome oxidase subunit 1 (COI) gene in Atyaephyra recognized seven Atyaephyra species in the Mediterranean basin in recent years. However, the lack of sampling in the Middle East does not help to clarify what Atyaephyra species are present in this region and their distributions. The most extended species in the area is $A$. orientalis, while $A$. tuerkayi has been found only in the River Nahr Al-Kabir, which is located along the borders of Lebanon with Syria. DNA barcodes of Atyaephyra specimens collected in this study confirm the first record of $A$. tuerkayi in Turkey. In addition, Palaemon turcorum, an endemic species to the Sakarya River Basin which flows into the Black sea was collected outside this basin, in rivers of the Mediterranean coast. The fact that the Middle East has not been well surveyed for shrimp could explain the unknown distribution of these species.
\end{abstract}

\section{Introduction}

Most biodiversity is unknowable because of: the regions in the world that have not been surveyed well, the relative neglect of taxonomy, the growing evidence of multiple cryptic species, and the high predicted rate of extinction has not allowed the scientific communities to know the former fauna (e.g.: Barnosky et al., 2011; Macpherson \& Machordom, 2005). Regional ecosystems such as estuaries and coastal communities are rapidly losing populations, species, or entire functional groups (Lotze et al., 2006; Jackson et al., 2001). Habitat loss and alteration, excessive nutrient and sewage inputs, chemical contaminations, and overfishing are traditional anthropogenic activities which have a high impact on inland and transitional waters (Kennish, 2002). However, freshwater transfers between basins are turning into a problem, especially in the aridest Mediterranean regions, where extraordinary droughts periodically occur (Baptista et al., 2010; Cyrus et al., 2011). Man-made reservoirs modify natural river discharges, affecting physicochemical conditions of the estuaries and the dynamic population of the species (González-Ortegón et al., 2016), which is critical to survival and meta-population dynamics (Fahrig \& Merriam, 1985; Levins, 1970).

Atyaephyra de Brito Capello, 1867 is the most widespread atyid taxon in the Mediterranean region with its native range spanning from the Middle East to North Africa, a large part of Southern Europe, and to some Mediterranean islands (d'Udekem d'Acoz, 1999). Currently, this genus is represented by 7 valid species, 8 according to WoRMS (http://www.marinespecies.org/ aphia.php?p=taxdetails\&id=234114, August 24, 2020), because they consider $A$. acheronensis Christodoulou, Antoniou, Magoulas \& Koukouras (2012) as a valid species, although García Muñoz et al. (2014) showed that it is a synonym of $A$. desmarestii (Millet, 1831). The 
other 6 valid species are $A$. stankoi Karaman, 1972; $A$. orientalis Bouvier, 1913; A. thyamisensis Christodoulou, Antoniou, Magoulas \& Koukouras, 2012; A. strymonensis Christodoulou, Antoniou, Magoulas \& Koukouras, 2012; A. tuerkayi Christodoulou, Antoniou, Magoulas \& Koukouras, 2012; and A. vladoi Jabłońska, Mamos, Zawal \& Grabowski, 2018.

These species typically inhabit headwaters and the middle stretch of rivers, but seasonal river discharges typical of Mediterranean basins can displace some populations towards the oligohaline zones of estuaries (González-Ortegón et al., 2015; Cuesta et al., 2006) and they could be coexisting with freshwater and/or brackish water species of the genus Palaemon. These freshwater shrimps are sensitive to the water oxygenation level (González-Ortegón et al., 2012) and the human impacts on their habitat, especially in the Mediterranean region, making these species highly susceptible to the risk of extinction. However, the extent of this species wider distribution in the Mediterranean region is unknown despite the recent effort to recognize and delimit species within Atyaephyra due to the high number of cryptic species (García Muñoz et al., 2009, 2014; Christodoulou et al., 2012; Jablonska et al., 2018). The Middle Eastern region is one example where the lack of surveys does not allow accurate knowledge concerning the distribution of the Atyaephyra species (De Grave, 2013). For example, until now only $A$. orientalis Bouvier, 1913 had been recorded in Turkey (Özbek et al., 2004, 2009; Özbek \& Ustaoğlu, 2005) and thus detailed studies of the Atyaephyra populations in the Middle East are necessary to clarify the number of Atyaephyra species in this region, considering the new advances in the composition of the species of this genus (García Muñoz et al., 2009, 2014; Christodoulou et al., 2012; Jablonska et al., 2018).

The aim of this study is to provide knowledge on the current geographic distribution of the Atyaephyra species in the Middle Eastern region. We hypothesized that the restricted geographical distributions where $A$. thyamisensis, $A$. strymonensis, and $A$. tuerkayi had already been described, did not reflect the real distribution of these species, and surely some of them inhabited nearby regions, as already proved for $A$. thyamisensis reported in Albania and Macedonia (Jablonska et al., 2018).

\section{Materials and Methods}

Specimens of the genus Atyaephyra were collected in several estuaries and lakes from the coastal waters of Antalya (Turkey) using nets. In November 2008, 46 specimens of Palaemon turcorum (Holthuis, 1961) and 20 specimens of the genus Atyaephyra were collected from the Yamansaz coastal lake (Kemerağzi, Turkey) and 20 specimens of $P$. turcorum and 48 of Atyaephyra sp. were collected from Kirkgöz spring lake (Döşemealti, Antalya, Turkey). These specimens were preserved in 5\% buffered formalin (Figure 1; Table 1).

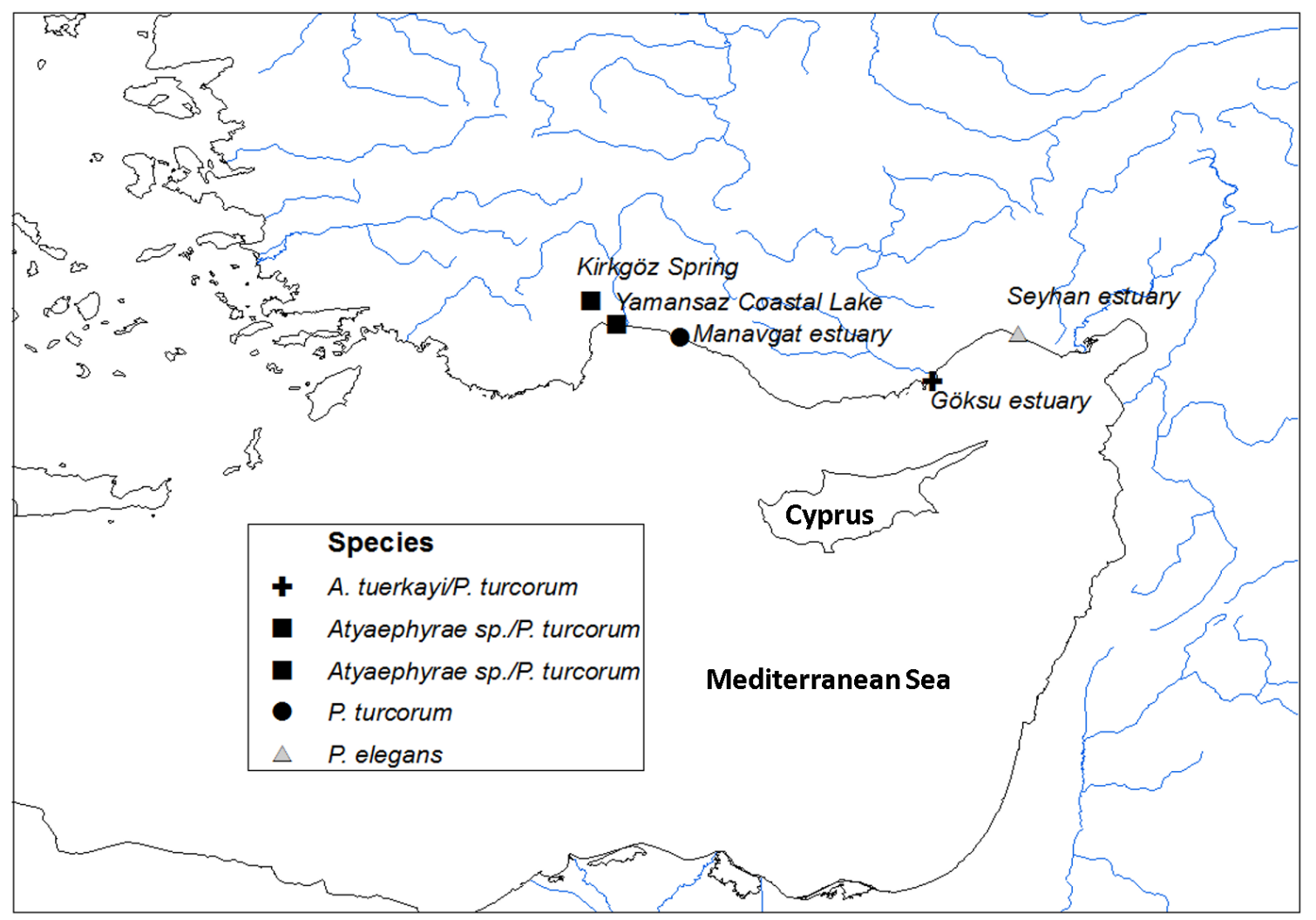

Figure 1. Sampling sites and caridean shrimp species found in the middle eastern region. Cross, square, circle, and triangle points indicate sites where, respectively, the species A. tuerkayi/Palaemon turcorum, Atyaephyra sp./P. turcorum, P. turcorum, and Palaemon elegans have been detected in this study. 
Table 1. Locations, year, depth, salinity, temperature, and environmental conditions of shrimp sampling surveys conducted along the Southern coast in Turkey between 2008 and 2015

\begin{tabular}{|c|c|c|c|c|c|c|c|}
\hline Locality & Latitude & Longitude & Year(s) & $\begin{array}{c}\text { Depth } \\
\text { Range }(\mathrm{m})\end{array}$ & Salinity & 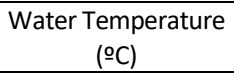 & Habitat Type \\
\hline Göksu estuary & $36^{\circ} 17^{\prime} 46.01^{\prime \prime} \mathrm{N}$ & $34^{\circ} 2^{\prime} 41.30^{\prime \prime} \mathrm{E}$ & 2014,2015 & $<1$ & $1-26$ & $9-20$ & mud and long dense eelgrass \\
\hline Kirkgöz spring & $37^{\circ} 6^{\prime} 30.67^{\prime \prime} \mathrm{N}$ & $30^{\circ} 34^{\prime} 58.54^{\prime \prime} \mathrm{E}$ & 2008 & $<1$ & $<1$ & $12-20$ & Gravel and riparian vegetation \\
\hline Yamansaz coastal lake & $36^{\circ} 52^{\prime} 17.39^{\prime \prime} \mathrm{N}$ & $30^{\circ} 50^{\prime} 30.26^{\prime \prime} \mathrm{E}$ & 2008 & $<1$ & $<1$ & $14-20$ & Gravel with green algae \\
\hline Manavgat estuary & $36^{\circ} 44^{\prime} 19.34^{\prime \prime} \mathrm{N}$ & $31^{\circ} 29^{\prime} 23.95^{\prime \prime} \mathrm{E}$ & 2015 & $<1$ & $1-26$ & $9-20$ & mud and long dense eelgrass \\
\hline Seyhan estuary & $36^{\circ} 46^{\prime} 43.18^{\prime \prime} \mathrm{N}$ & $34^{\circ} 54^{\prime} 39.91^{\prime \prime} \mathrm{E}$ & 2015 & $<1.5$ & $1-26$ & $9-20$ & mud and long dense eelgrass \\
\hline
\end{tabular}

Between 2014 and 2015, 6 and 7 specimens of $P$. turcorum were collected from the Manavgat and Göksu river estuaries, respectively, 6 specimens of Palaemon elegans Rathke, 1837 from the Seyhan River and 2 specimens of Atyaephyra sp. from the Göksu River, which were preserved in analytical grade $96 \%$ ethanol.

The specimens of Atyaephyra sp. from Turkey used in the present study were morphologically identified according to Christodoulou et al. (2012) and photographed (Figure 2). Two specimens were deposited in the Decapoda and Stomatopoda Crustacean Collection (Spanish Institute of Oceanography in Cadiz, Spain) under the catalog numbers IEO-CD-CCDE15/1475 and 1476.

Total genomic DNA was extracted from pleon muscle tissue of one male specimen of Atyaephyra sp., collected from the Göksu estuary (2015), following a modified Chelex $10 \%$ protocol by Estoup et al. (1996). Partial sequences of the mitochondrial $16 \mathrm{~S}$ and COI genes were amplified. Cycling conditions of the polymerase chain reaction (PCR), length of the sequences obtained, and primers used for each gene are the same as those in previous works (see Perez-Miguel et al., 2019). PCR products were sent to Stab-Vida laboratories to be purified and then bi-directionally sequenced. The sequences were edited using the software Chromas v. 2.0, and assembled in Bioedit (Hall, 1999). The final DNA sequences obtained were compared with those of the Atyaephyra species retrieved from the GenBank database.

New sequences of $16 \mathrm{~S}$ and $\mathrm{COI}$ are deposited in GenBank under the accession numbers MW020260 and MW020377, respectively.

\section{Results}

Taking into account the descriptions of the Atyaephyra species (García Muñoz et al., 2014; Christodoulou et al., 2012; Jablonska et al., 2018) from the Mediterranean region and comparing them with the specimens of Atyaephyra collected from the Yamansaz coastal lake and Kirgöz Spring, these look morphologically more similar to $A$. orientalis, and those from the Göksu estuary to $A$. tuerkayi (Figure 2). Although, it is worth bearing in mind, and given the morphological variability within the genus Atyaephyra, that other species of this genus should not be discarded (Figure 2). The main differences were observed in the rostrum, 20 specimens (mainly females and some indeterminate individuals) from the Yamansaz coastal lake exhibited a dorsal margin that is slightly curved in the middle; from 13-17 preorbital teeth on the dorsal margin of the rostrum, $0-2$ postorbital teeth and 4-8 teeth on the ventral margin of the rostrum. From the Kirkgöz spring lake, 31 specimens (mainly females, including 2 ovigerous females, and the rest indeterminate) showed a dorsal that is margin slightly curved in the middle or strongly curved in the middle and pointed upwards, from 17-20 preorbital teeth on the dorsal margin of the rostrum, 0-2 postorbital teeth and 5-10, mostly 10 teeth, on the ventral margin of the rostrum. The two males from the Göksu river estuary showed a straight dorsal margin, from 21-22 pre-orbital teeth on the dorsal margin of the rostrum, 1-2 postorbital teeth, and 8 teeth on the ventral margin of the rostrum. But, according to the rest of the features they could be identified as A. tuerkayi. The first pleopod in the male has a well-developed endopod, straight or bent outwards, bearing 7 to 8 spines on its edge. The distal part of the endopod, either curved inside or straight, ended with numerous cincinnuli (Figure 3A). The second pleopod in male has an appendix interna of endopod 5 times as long as wide, about 0.5 times the length of the appendix masculina, with numerous subterminal cincinnuli. The appendix masculina is 8 times as long as wide, bearing 8 spines on its proximal two-thirds; the endopod is shorter than the exopod and 7.1 times as long as its maximal width; the exopod is about 3.2 times as long as its maximal width (Figure $3 \mathrm{~B}$ ). The habitat conditions at these collection sites were consistent with the known habitats of Atyaephyra spp. (Table 1).

The preservation of the Göksu estuary specimens in ethanol in 2015 has allowed molecular analysis to confirm identification by DNA barcoding.

Specimens of Palaemon turcorum were collected from Göksu estuary, Kirkgöz spring, the Yamansaz coastal lake and Manavgat estuary, all in the Mediterranean basin (Figure 1). These are the first records for this species from outside the Sakarya Basin, where this species is known as an endemism (Holthuis, 1961). The most relevant features for assessing the identity of $P$. turcorum compared to $P$. antennarius $\mathrm{H}$. Milne Edwards, 1837, as well as from $P$. varians (Leach, 1813), P.zariquieyi (Sollaud, 1938) and $P$. mesopotamicus (Pesta, 1913) are the endopod of the first male pleopod almost as large as the exopod and in the appendix masculina of the second male pleopod which is far longer than the endopod of that pleopod (González-Ortegón \& Cuesta, 2006; Holthuis, 1961). 

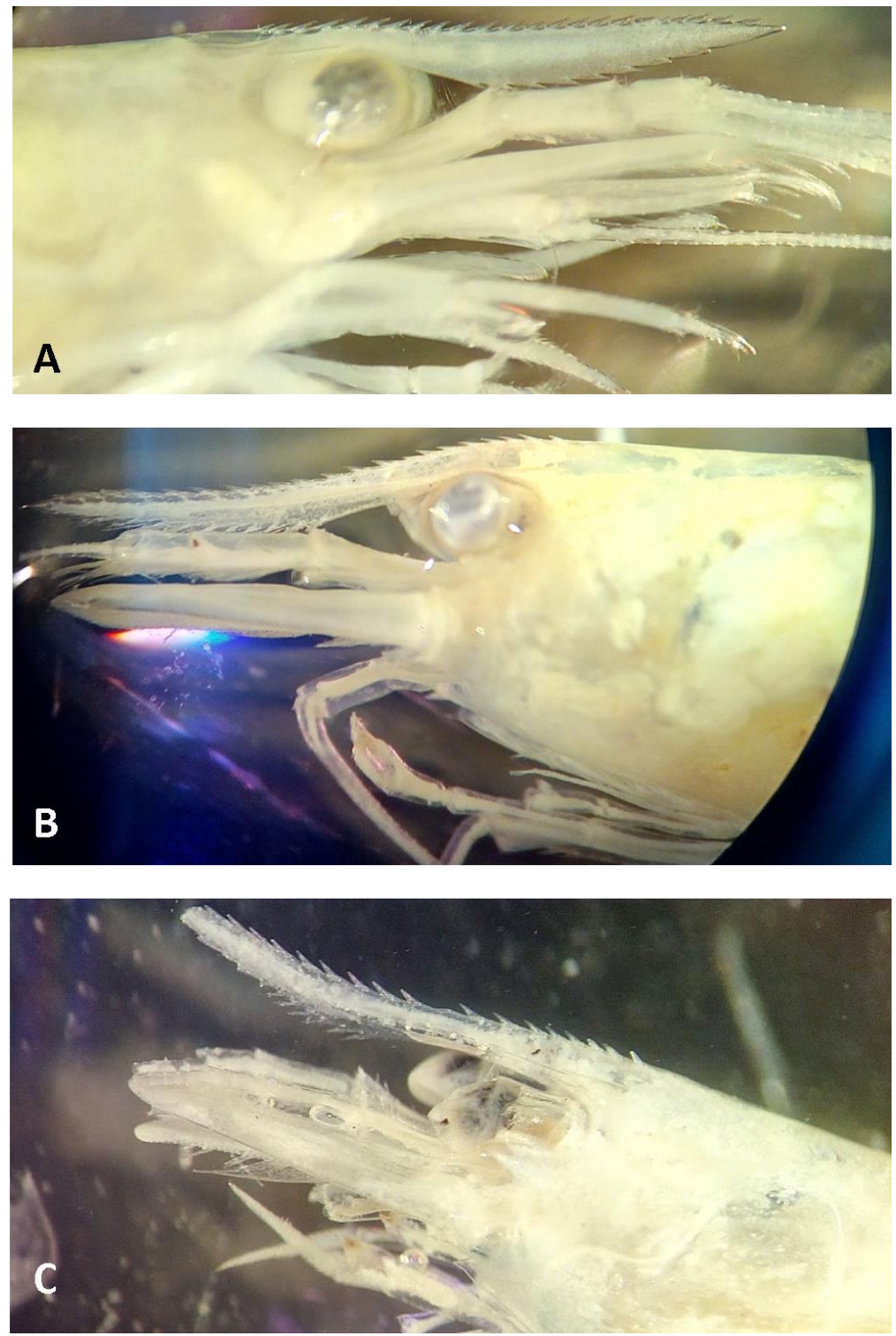

Figure 2. Photographs of Atyaephyra sp. species' cephalotorax collected in Turkey. A - Atyaephyra tuerkayi specimen from the Göksu river estuary; B - Atyaephyra orientalis from the Kirkgöz Spring; C - Atyaephyra sp. specimen from the Yamansaz coastal lake. Photographs by EGO.
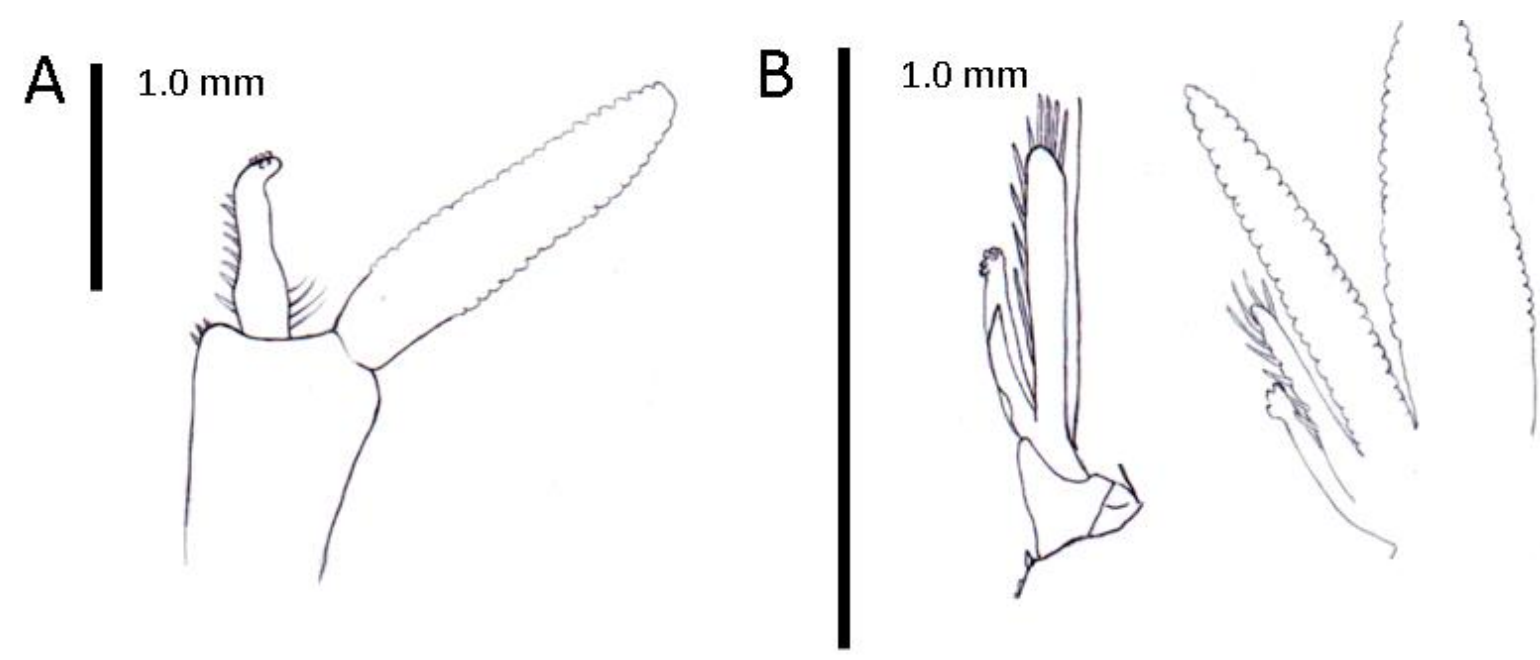

Figure 3. Atyaephyra tuerkayi Christodoulou, Antoniou, Magoulas \& Koukouras, 2012, male (IEO-CD-CCDE15/1475), from Göksu river estuary: $A$, right endopod of the first pleopod; $B$, right second pleopod. 


\section{DNA barcoding identification of Atyaephyra sp.}

The mitochondrial DNA sequence of COI generated from one male from the Göksu estuary consists of 667 bp and a $99.78 \%$ fit with the A. tuerkayi holotype (SMF43020) sequence (JX289935, 474 bp), and 99.75\% with $A$. tuerkayi paratype (SMF43021) sequence (JX289936, 406 bp). This new sequence increases in 193 bp the COI sequence for this species. This result strongly supports the idea that the specimens collected from the Göksu estuary belong to the species $A$. tuerkayi, with a low genetic variability concerning the Syrian specimens.

The DNA sequence of $16 \mathrm{~S}$ (544 bp) generated from the same specimen of the Göksu estuary cannot be used to compare with the only two DNA vouchers of $A$. tuerkayi, because, unfortunately, the authors describing A. tuerkayi did not include any sequences of the $16 \mathrm{~S}$ gene in their study. When this new sequence of $16 \mathrm{~S}$ is blasted on the homepage of NCBI (http://blast.ncbi.nlm.nih.gov), the maximum homology obtained is with 21 sequences of $A$. desmarestii (9395\%) (i.e. EU123848, JX469086, FJ594305-FJ594355), and one of $A$. orientalis (94.02\%)(JX469105).

\section{Discussion}

Our great ignorance of biodiversity probably allows many 'cryptic extinctions' to go undetected (Carlton, 1993). This work is one example of the diversity of cryptic species of the genus Atyaephyra and Palaemon that live in the Mediterranean basin without our knowing. The Mediterranean basin has a very complex geological history, with major events like the Messinian salinity crisis (5 Ma) and the Last Glacial Maximum $(18,000$ years ago) contributing to the high level of endemism found in peri-Mediterranean areas (Lejeusne et al., 2010; Reyjol et al., 2007). Rapid advances in molecular genetics are key to understanding the genetic variation (Storfer et al., 2010). In the present study, we are reporting a new occurrence of $A$. tuerkayi based mainly on data from a partial sequence of $\mathrm{COI}$ and the morphological features, and $P$. turcorum based on morphological features which match the previous descriptions. The fact that the Middle East has not been well surveyed for freshwater and estuarine shrimps could suggest that its potentially wider distribution is unknown (De Grave, 2013). This finding suggests that $P$. turcorum and $A$. tuerkayi are potentially distributed in the Antalya peninsula and could be coexisting with the species $A$. orientalis. In the case of $A$. tuerkayi, previous specimens were collected in 1979 from the Nahr AlKabir River (between Lebanon and Syria), close to the sea (Christodoulou et al., 2012), they are considered on the IUCN Red List as Data Deficient. This new finding of a population of $A$. tuerkayi could lead to a reconsideration of this category on the IUCN Red List. Despite the high morphological variability found, specimens from the Yamansaz coastal lake and Kirkgöz Spring could be identified as $A$. orientalis. The results of these two populations have limited conclusive significance, as the individuals could not be used for genetic analyses.

The Mediterranean basin is one of the regions most vulnerable to climate change (Ribas et al., 2010), and several studies have shown that it is already facing the impacts of climate change on water yields (e.g. Ludwig et al., 2011). The long-term unsustainable use of water resources leading to water scarcity is common in semi-arid regions, such as the Mediterranean region, where endemic freshwater species have been reported among the most threatened biota in the world (Hermoso \& Clavero, 2011). Although data on freshwater invertebrates are limited, the latent effects of water scarcity should not pass unnoticed for small populations of caridean shrimps such as the species $A$. tuerkayi. The strong genetic differentiation at spatial scales of the species of Atyaephyra has been shown recently (García-Muñoz et al., 2009, 2014; Christodoulou et al., 2012; Jablonska et al., 2018). In this arid region, with a dominance of small basins and regulated streams, the extended drought events lead to a loss of hydrologic connectivity between stream compartments (Sabater \& Tockner, 2009). The geographic distribution of atyid species seems to be affected by freshwater availability and quality, especially in the smallest basins such as the coastal lake Yamansaz (Kemerağzi, Turkey) and may increase the risk of extinction of this population of the genus Atyaephyra with species pending confirmation (e.g. Holmquist et al., 1998; Benstead et al., 1999). If the environmental scenario of water scarcity under global warming remains unchanged, Mediterranean coastal species will be one of the most threatened biotas in the world.

\section{Conflict of Interest}

The authors declare that they have no conflict of interest.

\section{Authors' Contributions}

EGO conceived and designed the research. DY: performed the fieldwork. EGO and JAC: analyzed the species. EGO: wrote the first draft of the manuscript. All authors read and approved the final manuscript.

\section{Acknowledgements}

We would like to thank two anonymous referees for their valuable comments and suggestions that clearly improved the manuscript, and Carlos Sánchez (ICMANCSIC) by laboratory work.

\section{References}

Baptista, J., Martinho, F., Dolbeth, M., Viegas, I., Cabral, H., \& Pardal, M. (2010). Effects of freshwater flow on the fish assemblage of the Mondego estuary (Portugal): 
comparison between drought and non-drought years. Marine and Freshwater Research, 61(4), 490-501.

Barnosky, A.D., Matzke, N., Tomiya, S., Wogan, G.O.U., Swartz, B., Quental, T.B., Marshall, C., McGuire, J.L., Lindsey, E.L., Maguire, K.C., Mersey, B., \& Ferrer, E.A. (2011). Has the Earth's sixth mass extinction already arrived? Nature, 471(7336), 51-57.

https://doi.org/10.1038/nature09678

Benstead, J.P., March, J.G., Pringle, C.M., \& Scatena, F.N. (1999). Effects of a low-head dam and water abstraction on migratory tropical stream biota. Ecological Applications, 9(2), 656-668.

Carlton, J.T. (1993). Neoextinctions of marine invertebrates. American Zoologist, 33(6), 499-509.

Christodoulou, M., Antoniou, A., Magoulas, A., \& Koukouras, A. (2012). Revision of the freshwater genus Atyaephyra (Crustacea, Decapoda, Atyidae) based on morphological and molecular data. ZooKeys, 229, 53-110.

Cuesta, J.A., González-Ortegón, E., Rodríguez, A., Baldó, F., Vilas, C., \& Drake, P. (2006). The decapod crustacean community of the Guadalquivir Estuary (SW Spain): Seasonal and inter-year changes in community structure. Hydrobiologia, 557, 85-95.

Cyrus, D., Jerling, H., Mackay, F., \& Vivier, L. (2011). Lake St Lucia, Africa's largest estuarine lake in crisis: combined effects of mouth closure, low levels and hypersalinity. South African Journal of Science, 107(3-4), 01-13.

De Grave, S. (2013). Atyaephyra tuerkayi. The IUCN Red List of Threatened Species 2013: e.T42428295A42461512

Fahrig, L., \& Merriam, G. (1985). Habitat patch connectivity and population survival: Ecological archives e066-008. Ecology, 66(6), 1762-1768.

García Muñoz, J.E., Rodríguez, A., García Raso, J.E., \& Cuesta, J.A. (2009). Genetic evidence for cryptic speciation in the freshwater shrimp genus Atyaephyra de Brito Capello (Crustacea, Decapoda, Atyidae). Zootaxa, 2025(1), 3242.

García Muñoz, J.E., García Raso, J.E., Rodríguez, A., \& Cuesta, J.A. (2014). Cryptic speciation of Greek populations of the freshwater shrimp genus Atyaephyra de Brito Capello, 1867 (Crustacea, Decapoda), evidence from mitochondrial DNA. Zootaxa, 3790(3), 401-424.

González-Ortegón, E., \& Cuesta, J.A. (2006). An illustrated key to species of Palaemon and Palaemonetes (Crustacea: Decapoda: Caridea) from European waters, including the alien species Palaemon macrodactylus. Marine Biological Association of the United Kingdom. Journal of the Marine Biological Association of the United Kingdom, 86(1), 93.

González-Ortegón, E., Rodríguez, A., \& Drake, P. (2012). The freshwater shrimp Atyaephyra desmarestii (Millet, 1831) as a bioindicator of hypoxic event effects on temperate freshwater systems. Ecological Indicators, 18, 236-242.

González-Ortegón, E., Baldó, F., Arias, A., Cuesta, J.A., Fernández-Delgado, C., Vilas, C., \& Drake, P. (2015). Freshwater scarcity effects on the aquatic macrofauna of a European Mediterranean-climate estuary. Science of the Total Environment, 503, 213-221.

González-Ortegón, E., Palero, F., Lejeusne, C., Drake, P., \& Cuesta, J.A. (2016). A salt bath will keep you going? Euryhalinity tests and genetic structure of caridean shrimps from Iberian rivers. Science of the Total Environment, 540, 11-19.

Hall, T.A. (1999). BioEdit: A user-friendly biological sequence alignment editor and analysis program for Windows
95/98/NT. Nucleic Acids Symposium Series, 41, 95-98.

Hermoso, V., \& Clavero, M. (2011). Threatening processes and conservation management of endemic freshwater fish in the Mediterranean basin: a review. Marine and Freshwater Research, 62(3), 244-254.

Holmquist, J.G., Schmidt-Gengenbach, J.M., \& Yoshioka, B.B. (1998). High dams and marine-freshwater linkages: effects on native and introduced fauna in the Caribbean. Conservation Biology, 12(3), 621-630.

Holthuis, L.B. (1961). Report on a collection of crustacea decapoda and stomatopoda from Turkey and the Balkans. Zoologische Verhandelingen Leiden, 47, 1-67.

Jabłońska, A., Mamos, T., Zawal, A., \& Grabowski, M. (2018). Morphological and molecular evidence for a new shrimp species, Atyaephyra vladoi sp. nov. (Decapoda, Atyidae) in the ancient Skadar Lake system, Balkan Peninsula-its evolutionary relationships and demographic history. Zoologischer Anzeiger, 275, 66-79.

Lejeusne, C., Chevaldonné, P., Pergent-Martini, C., Boudouresque, C.F., \& Pérez, T. (2010). Climate change effects on a miniature ocean: the highly diverse, highly impacted Mediterranean Sea. Trends in Ecology \& Evolution, 25(4), 250-260.

Levins, R. (1970). Extinction. Lectures on mathematics in the life sciences. Volume 2 . Some mathematical questions in biology. American Mathematical Society, Providence, Rhode Island.

Jackson, J.B., Kirby, M.X., Berger, W.H., Bjorndal, K.A., Botsford, L.W., Bourque, B.J., Bradbury, R.H., Cooke, R., Erlandson, J., \& Estes, J.A. (2001). Historical overfishing and the recent collapse of coastal ecosystems. Science, 293(5530), 629-637.

Kennish, M.J. (2002). Environmental threats and environmental future of estuaries. Environmental conservation, 29, 78-107.

Lotze, H.K., Lenihan, H.S., Bourque, B.J., Bradbury, R.H., Cooke, R.G., Kay, M.C., Kidwell, S.M., Kirby, M.X., Peterson, C.H., \& Jackson, J.B.C. (2006). Depletion, Degradation, and Recovery Potential of Estuaries and Coastal Seas. Science, 312(5781), 1806.

Ludwig, R., Roson, R., Zografos, C., \& Kallis, G. (2011). Towards an inter-disciplinary research agenda on climate change, water and security in Southern Europe and neighboring countries. Environmental Science \& Policy, 14(7), 794803.

Macpherson, E., \& Machordom, A. (2005). Use of morphological and molecular data to identify three new sibling species of the genus Munida Leach, 1820 (Crustacea, Decapoda, Galatheidae) from New Caledonia. Journal of Natural History, 39(11), 819-834.

Özbek, M., Balık, S. \& Ustaoğlu, M.R. (2004). Malacostraca (Crustacea) Fauna of Yuvarlak Stream (Köyceğiz- Muğla). Turkish Journal of Zoology, 28, 321-327.

Özbek, M., Balık, S. \& Topkara, E.T. (2009). Contribution to the knowledge on the distribution of Malacostraca (Crustacea) species of central and southern Anatolia, with some ecological notes. Turkish Journal of Zoology, 33, 47-55.

Özbek, M. \& Ustaoğlu, M.R. (2005). Taxonomical investigation of Lake District inland waters Malacostraca (CrustaceaArthropoda) fauna. Ege Journal of Fisheries and Aquatic Sciences, 22 (3-4), 357-362.

Perez-Miguel, M., Drake, P., García Raso, J.E., Menéndez, L.M., Navas, J.I., \& Cuesta, J.A. (2019). European Pinnotheridae (Crustacea, Decapoda, Brachyura): 
species, distribution, host use and DNA barcodes. Marine Biodiversity, 49(1), 57-68.

Reyjol, Y., Hugueny, B., Pont, D., Bianco, P.G., Beier, U., Caiola, N., Casals, F., Cowx, I., Economou, A., Ferreira, T., Haidvogl, G., Noble, R., De Sostoa, A., Vigneron, T. \& Virbickas, T. (2007). Patterns in species richness and endemism of European freshwater fish. Global Ecology and Biogeography, 16(1), 65-75.

Ribas, A., Calbó, J., Llausas, A., \& Lopez-Bustins, J.A. (2010). Climate change at the local scale: trends, impacts and adaptations in a Northwestern Mediterranean Region (Costa Brava, NE Iberian Peninsula). International Journal of Climate Change: Impacts and Responses, 2(1), 247-264.
Sabater, S., \& Tockner, K. (2009). Effects of hydrologic alterations on the ecological quality of river ecosystems. In Water scarcity in the Mediterranean (pp. 15-39). Springer, Berlin, Heidelberg.

Storfer, A., Murphy, M.A., Spear, S.F., Holderegger, R., \& Waits, L.P. (2010). Landscape genetics: where are we now? Molecular ecology, 19(17), 3496-3514.

d'Udekem d'Acoz, C. (1999). Inventaire et distribution des crustacés décapodes de l'Atlantique nord-oriental, de la Méditerranée et des eaux continentales adjacentes au nord de $25^{\circ}$ N. Patrimoines Naturels (M.N.H.N./P.N.), 40,1-383. 